Research Paper

\title{
Modeling of pressure effects on flame structure and soot formation of $n$-heptane/air co-flow laminar flames by skeletal reaction mechanism
}

\author{
Sen $\mathrm{Li}^{*}$

\section{H I G H L I G H T S} \\ - Flame structure and the formation paths of soot and PAHs are presented. \\ - The flame radius decreases with pressure as $p^{-1 / 2}$. \\ - Maximum volume concentration of soot increases with pressure as $p^{2}$. \\ - Soot is easily formed in the region of $1200 \mathrm{~K}$ and $0.08 \sim 0.09$ mixture fraction. \\ - Maximum carbon conversion to soot is proportional to pressure at 0.1 2.0 MPa.
}

State Key Laboratory of High Temperature Gas Dynamics, Institute of Mechanics, Chinese Academy of Sciences, No.15 Beisihuanxi Road, Beijing 100190 , China

\section{A R T I C L E I N F O}

\section{Article history:}

Received 8 September 2015

Accepted 1 March 2016

Available online 20 April 2016

\section{Keywords:}

Flame structure

Soot formation

Pressure

n-heptane

Skeletal mechanism

\begin{abstract}
A B S T R A C T
The conversion from chemical energy to thermal energy by the high-pressure combustion of hydrocarbon fuel/air is often accompanied by pollution emissions of PAHs and soot in aircraft gas turbines and diesel engines, and the measurement and analysis of PAHs and soot formations in the practical turbulent flame of engines are difficult. In the study, based on the simulation of the simple laminar co-flow diffusion flame of $n$-heptane/air by the developed skeletal reaction mechanism, the effects of pressure on flame structure and soot formation are investigated. The results indicate that flame height keeps constant at 0.7 3.0 MPa; the flame radius decreases with pressure as $p^{-1 / 2}$; the maximum carbon conversion to soot $\left(\eta_{\mathrm{s}, \max }\right)$ is proportional to pressure at $0.1 \sim 2.0 \mathrm{MPa}$; the maximum soot volume concentration $\left(f_{\mathrm{v}, \max }\right)$ increases with pressure as $p^{2}$; the locations of $f_{\mathrm{v}, \max }$ and $\eta_{\mathrm{s}, \max }$ along flame centerline are inconsistent, and $f_{\mathrm{v}, \max }$ and $\eta_{\mathrm{s}, \max }$ occur respectively at the middle and lower parts of flame height; $f_{\mathrm{v}, \max }$ occurs in the region where the mixture fraction and temperature are respectively $0.08 \sim 0.09$ and about $1200 \mathrm{~K}$. The diffusion flame consists of three zones: fuel heating zone, fuel-rich reaction zone and oxidizer-rich reaction zone. $n-\mathrm{C}_{7} \mathrm{H}_{16}$ is firstly decomposed into small molecule gas (e.g., $\mathrm{H}_{2}, \mathrm{CH}_{4}, \mathrm{C}_{2} \mathrm{H}_{2}, \mathrm{C}_{2} \mathrm{H}_{4}, \mathrm{C}_{2} \mathrm{H}_{6}, \mathrm{C}_{3} \mathrm{H}_{4}, \mathrm{C}_{3} \mathrm{H}_{6}$, etc.) in the heating zone, and PAHs $\left(\mathrm{C}_{6} \mathrm{H}_{6}, \mathrm{C}_{8} \mathrm{H}_{8}\right.$ and $\left.\mathrm{C}_{10} \mathrm{H}_{8}\right)$ and soot precursors $\left(\mathrm{C}_{2} \mathrm{H}_{2}, \mathrm{C}_{6} \mathrm{H}_{5}, \mathrm{C}_{6} \mathrm{H}_{6}\right.$ and $\left.\mathrm{C}_{2} \mathrm{H}_{4}\right)$ are formed in fuel-rich reaction zone.
\end{abstract}

(ㄷ) 2016 Elsevier Ltd. All rights reserved.

\section{Introduction}

The combustion of liquid hydrocarbon fuels plays a pivotal role in modern transportation devices (e.g., aircraft gas turbines and diesel engines), and it can effectively convert chemical energy of fuel into thermal energy of the combustion products expanding to drive the operation of engine. However, the practical high-pressure diffusion combustion (up to $4 \mathrm{MPa}$ ) introduces the formation of pollutants (e.g., polycyclic aromatic hydrocarbons (PAHs), soot and other particulate matters) in engines [1,2]. Soot emission increases the risk of heart problems, premature death, and lung cancer, and it is believed to be twice as potent an agent in global warming as carbon dioxide $[3,4]$. Our understanding of high-pressure combustion is

\footnotetext{
* Tel.: +8610 82544231; fax: +8610 82544231.

E-mail address: lisen@imechac.cn.
}

relatively limited due to the non-trivial nature of tractable highpressure combustion experiments and simulations [5-7].

The formation of PAHs and soot depends on the fuel characteristics and the combustion operating parameters (such as pressure and fuel/air ratio). In the practical high-pressure devices, the high level of intermittency due to turbulent motion and relatively short residence time involved in these flames is not always suitable for experimental measurements of combustion [6,7]. Compared to the turbulent combustion in practical combustion devices, a laminar coflow diffusion flame has the simplest configuration from which the interactions between flow field and reactions can be readily modified and studied, and many researchers adopted laminar co-flow diffusion flame to investigate soot formation [8,9].

$n$-heptane $\left(n-\mathrm{C}_{7} \mathrm{H}_{16}\right)$ is an important component of gasoline, diesel and kerosene, and it is also a primary reference fuel for octane rating in internal combustion engines [6,10]. In some studies of liquid hydrocarbon fuel combustion, $n$-heptane is thought to be a good 
surrogate fuel [6,11-14]. The combustion characteristics of $n$-heptane/air are very important for the design of niche engines. The accurate understanding of co-flow flame structure and pollutant formations (PAHs and soot) are crucial to investigate the highly complex reaction nature of hydrocarbon fuel at the high-pressure combustion condition of the practical engine operation, and it is very important for the design of niche engines.

The purpose of this study is to investigate the combustion characteristics of laminar co-flow diffusion flame of $n$-heptane/air by the developed skeletal reaction mechanism, the effects of pressure on the flame structure and soot formation are discussed, and the combustion reaction paths in different flame zones are analyzed.

\section{2. n-heptane/air skeletal mechanism formulation}

Consalvi and Liu [15] adopted a detailed reaction mechanism including 175 species and 1086 reactions to simulate laminar $n$-heptane/air diffusion flame, and it is much too costly to use the detailed chemical kinetic mechanism to couple with computational fluid dynamic (CFD) codes. Since the detailed mechanism of $n$-heptane-PAHs contains too many species and reactions developed by Wang et al. [16], the detailed mechanism is reduced by principal component analysis (PCA) in the study, and the skeletal mechanism includes 50 species and 241 reactions shown in Appendix S1. PCA is an advanced technique of sensitivity analysis to simplify detailed reaction mechanism, which is described in Sandor et al. [17].

To validate the skeletal mechanism reduced by PCA, the ignition delay time $\left(\tau_{\text {ign }}\right)$ of $n$-heptane/air is simulated using an adiabatic constant volume homogeneous reactor model by SENKIN program calculations. When the equivalence ratio of $n$-heptane/air, pressure and temperature are respectively 1.0, $40 \pm 2$ bar and 700-1200 K, the ignition delay time is extracted based on the steepest-increase criterion of $\mathrm{OH}$ mole fraction vs. time curve, and the predicted results are compared with Hartmann's experimental results [18], as shown in Fig. 1. The simulated results have excellent agreement with the measured data in the wide temperature range at high pressure. Since the ignition delay time can effectively reflect the combustion characteristics of $n$-heptane/air, the developed skeletal mechanism is valid to predict $n$-heptane/air combustion. The validation of the skeletal mechanism for the soot formation prediction of $n$-heptane/ air is presented in the following sections.

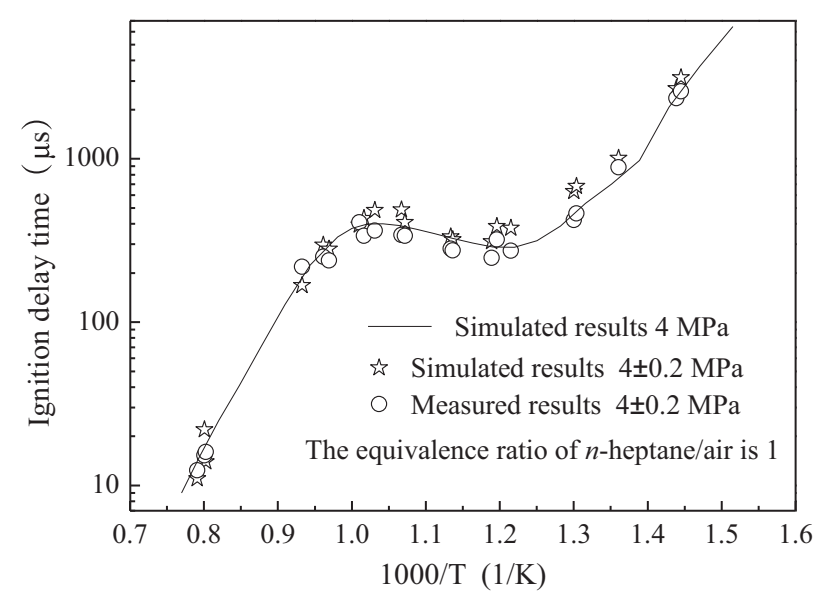

Fig. 1. Comparison of the measured and simulated ignition delay times of $n$-heptane/ air mixtures.

\section{Modeling method of laminar co-flow n-heptane/air flame}

The simulated experimental burner setup was described by Karatas et al. [10]. The burner was a coflow burner, and the diameters of fuel nozzle exit and air nozzle were respectively $3.06 \mathrm{~mm}$ and $25.4 \mathrm{~mm}$. In nitrogen-diluted $n$-heptane/air experiments, the flow rates of $n$-heptane and nitrogen were respectively set to $0.49 \mathrm{mg} / \mathrm{s}$ and $1.04 \mathrm{mg} / \mathrm{s}$ at $520 \mathrm{~K}$, and the flow rate of co-flow air was $0.42 \mathrm{~g} / \mathrm{s}$ at $475 \mathrm{~K}$.

In the simulation of nitrogen-diluted $n$-heptane/air co-flow flame, the skeletal chemical mechanism of $n$-heptane-PAHs is coupled with ANSYS Fluent code software. The transport equations of mass, momentum, energy, gas-phase species, soot mass fraction, soot number density, and radiation intensity are closed with the equation of state and appropriate boundary condition in axisymmetric cylindrical coordinates. Buoyancy is accounted by retaining the gravity term in the momentum equation. The above detailed algorithm was described by Liu et al. [19].

Moss-Brookes-Hall model was developed to predict soot formation of high hydrocarbon fuel [20], which was implanted in ANSYS Fluent code software to solve the transport equations for the normalized radical nuclei, growth and oxidation. In the simulation, the species of $\mathrm{C}_{2} \mathrm{H}_{2}, \mathrm{C}_{6} \mathrm{H}_{6}$ and $\mathrm{C}_{2} \mathrm{H}_{4}$ are considered as soot precursors and soot growth surface. The mass of incipient soot particle is $144 \mathrm{~g} / \mathrm{mol}$, and the mean density of soot particle is $2 \mathrm{~g} / \mathrm{cm}^{3}$. The radiations of gases $\left(\mathrm{H}_{2} \mathrm{O}, \mathrm{CO}\right.$ and $\left.\mathrm{CO}_{2}\right)$ and soot are modeled by the assumption of optically thin radiation transfer between a given fluid element (or soot) in the flame and the cold surroundings. In the simulation of experimental burner chamber, the domain is discretized by uniform hexahedral grid, and the total grids contain 28,368 cells.

\section{Results and discussion}

\subsection{Flame shapes}

Flame color often provides the observer with important information. The flame of rich-hydrocarbon/air mixtures can appear as luminous yellow due to the presence of high-temperature soot particles [21], which is more evident based on the direct viewing flame by eye or the conventional color image. Fig. 2 provides the comparisons of simulated sooting region and pictured luminous region in the laminar co-flow nitrogen-diluted $n$-heptane/air flames along the height above the burner (HAB) and radius ( $\mathrm{R}$ ) at 0.2 1.0 MPa. The yellow sooting region extends toward burner exit with the increase of pressure, and the shapes of the simulated sooting region well agree with pictured luminous region. Therefore, the laminar flame model coupled with the developed skeletal mechanism can effectively simulate laminar $n$-heptane/air diffusion flames.

In a diffusion flame, the combustion process depends more on the diffusion rate of reactants than on the rate of chemical reactions. Flame shape is an important characteristic of laminar diffusion flame, and it can be profoundly affected by pressure and mixture diffusion. In the study, as the fuel and oxidizer flow along the flame axis, fuel diffuses radially outward, oxidizer diffuses radially inward, and the flame surface is formed where the stoichiometric ratio (SR) of oxidizing species to combustible species is equal to 1 . The flame height is the height above the burner lip (HAB) at which flame surface crosses the axis along flame centerline, and flame radius $\left(r_{\mathrm{f}}\right)$ is defined as the radius of flame surface at the half of flame height.

To analyze the mixing of fuel and oxidizer in laminar diffusion flame, the mixture fraction $(\zeta)$ is defined, and the fraction of the total amount of material present came originally from fuel stream in flame. In $n$-heptane/air laminar flame, fuel $\left(n-\mathrm{C}_{7} \mathrm{H}_{16}\right)$ has only the 


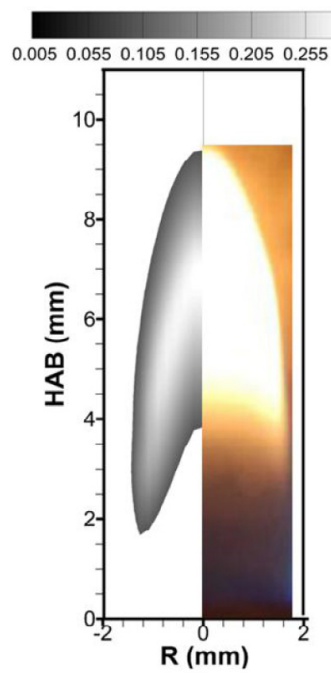

(a) $0.2 \mathrm{MPa}$

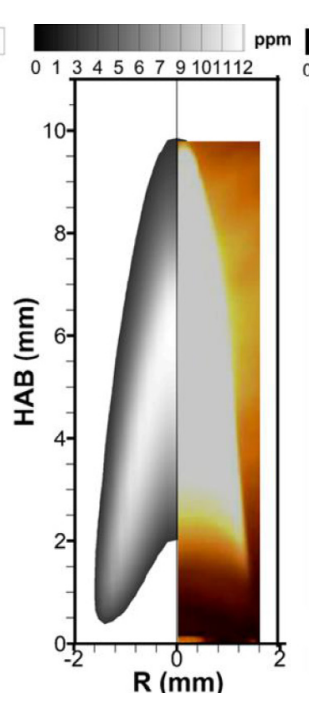

(b) $0.5 \mathrm{MPa}$

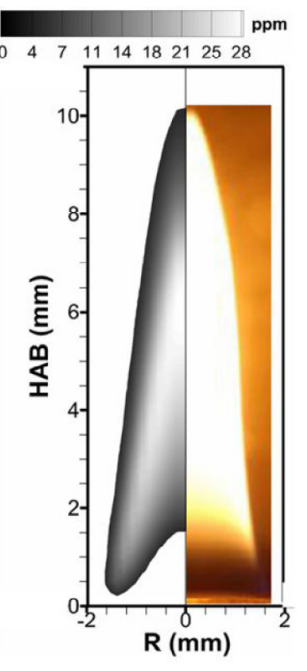

(c) $0.7 \mathrm{MPa}$

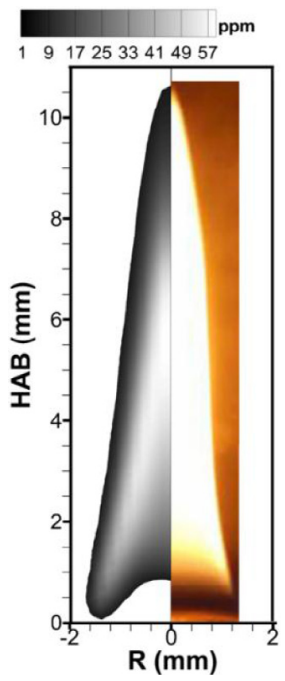

(d) $1.0 \mathrm{MPa}$

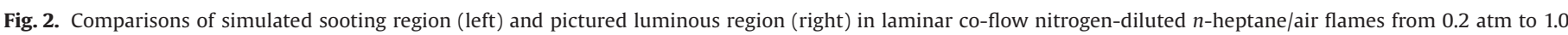
atm [10].

two elements of $\mathrm{C}$ and $\mathrm{H}$, air has only the two species of $\mathrm{N}_{2}$ and $\mathrm{O}_{2}$, thus the mixture fraction is

$\zeta=\frac{\sum N_{\mathrm{Ci}} \chi_{\mathrm{i}} \mathrm{MW}_{\mathrm{C}}+\sum N_{\mathrm{Hi}} \chi_{\mathrm{i}} \mathrm{MW}_{\mathrm{H}}}{\mathrm{MW}_{\text {mix }}}$

where, $N_{\mathrm{C} i}$ and $N_{\mathrm{Hi}}$ are the atom numbers of $\mathrm{C}$ and $\mathrm{H}$ in species $i ; X_{i}$ is the mole fraction of species $i$ in mixture; $\mathrm{MW}_{\mathrm{C}}, \mathrm{MW}_{\mathrm{H}}$ and $\mathrm{MW}_{\text {mix }}$ are the molar masses of $\mathrm{C}, \mathrm{H}$ and mixture, respectively. In the study, the mixture fraction of nitrogen-diluted $n$-heptane/air is 0.055 at $S R=1$. Fig. 3 shows the variations of flame surface shape, the radius and crosssectional area of nitrogen-diluted $n$-heptane/air co-flow laminar flame with pressure. Fig. 3a shows the shapes of flame surfaces where $\zeta$ is equal to 0.055 . With the increase of pressure, flame surface becomes narrower, whereas flame height keeps constant (about $9 \mathrm{~mm}$ ) at 0.7 3.0 MPa. The simulation result of flame height is nearly close to the experiment result of Karatas et al. [10]. Fig. 3b shows the relationships of flame radius and cross-sectional area with pressure, the flame radius $\left(r_{\mathrm{f}}\right)$ decreases with pressure $(p)$ as $r_{\mathrm{f}} \propto p^{-1 / 2}$, the product of crosssectional area $\left(A_{\mathrm{f}}\right)$ and pressure is approximately equal to a constant, and the results have agreements with the experimental results using methane and propane [15,22-24].

Fig. 4 shows the distributions of axial velocity along the flame centerline at 0.7 3.0 MPa. At a given $\mathrm{HAB}$, the axial velocity keeps almost constant with pressure. Since the average velocity of laminar flame cross-sectional area is half of the centerline velocity, the average velocity of cross-sectional area also keeps constant at 0.7 3.0 MPa, thus the combustion residence time is independent of pressure. At the meantime, since the density of flame mixture increases with increasing pressure, the flow within the flame envelope will be through a narrower cross-section area with increasing pressure to conserve mass (see Fig. 3a).

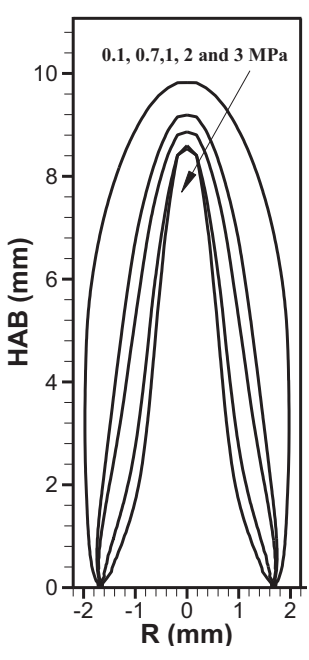

(a) flame surface

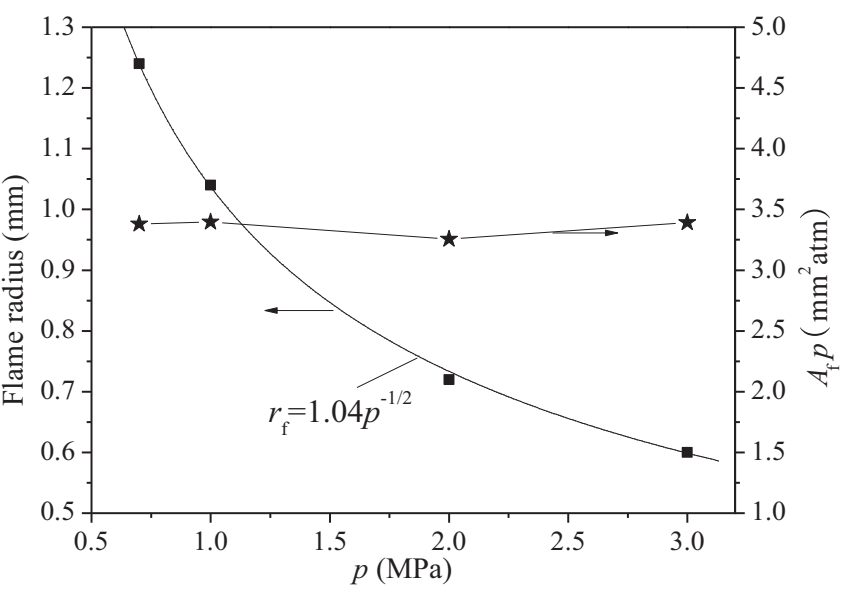

(b) flame radius and cross-sectional area

Fig. 3. The variations of flame surface shape, radius and cross-sectional area of nitrogen-diluted $n$-heptane/air co-flow with pressure. 


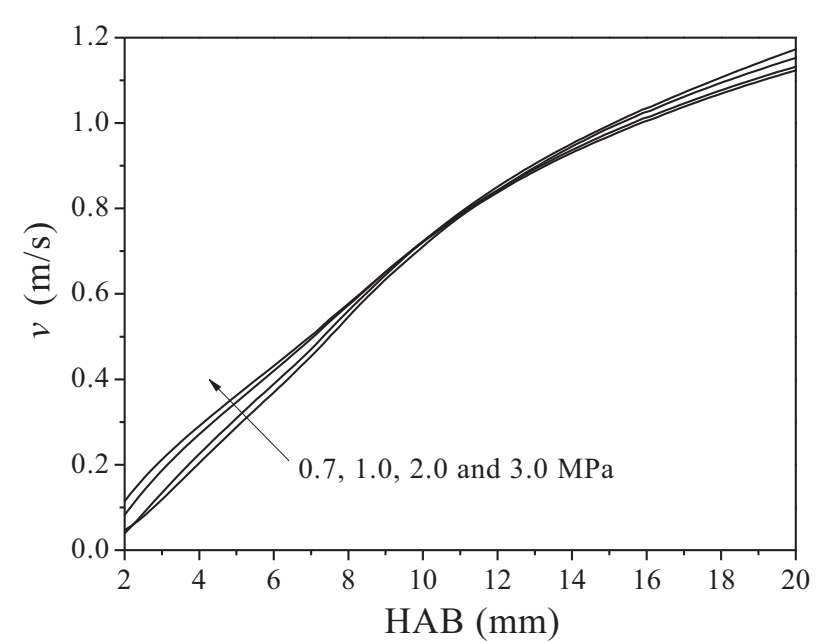

Fig. 4. Distributions of axial velocity along the flame centerline at 0.7 3.0 MPa.

\subsection{Effect of pressure on soot formation}

As suggested by Joo and Gülder [14] and Thomson et al. [23], the percentage of carbon in the fuel converted to soot $\left(\eta_{s}\right)$ is used to assess the sooting sensitivity of laminar diffusion flames at elevated pressures, and $\eta_{s}$ is defined as

$\eta_{\mathrm{s}}=\frac{\dot{m}_{\mathrm{s}}}{\dot{m}_{\mathrm{c}}} \times 100$

where $\dot{m}_{\mathrm{c}}$ is the carbon mass-flow rate in fuel at the nozzle exit, and $\dot{m}_{\mathrm{s}}$ is the carbon mass flow rate in soot at the horizontal crosssection of flame:

$\dot{m}_{\mathrm{s}}=2 \pi \rho_{\mathrm{s}} \int f_{\mathrm{v}}(r, z) v_{z}(z) r \mathrm{~d} r$

where $\rho_{\mathrm{s}}$ is soot density, $f_{\mathrm{v}}(r, z)$ is the local soot volume fraction at the position $r$ (radial) and $z$ (axial), and $v_{z}(z)$ is the axial velocity.

Fig. 5 shows the effect of pressure on carbon conversion to soot at $0.5 \sim 2.0 \mathrm{MPa}$, and the location of maximum carbon conversion $\left(\eta_{\mathrm{s}, \mathrm{max}}\right)$ along HAB decreases from 4.5 to $3.5 \mathrm{~mm}$ with the increase of pressure from 0.5 to $2.0 \mathrm{MPa}$. Fig. 6 shows the variation of $\eta_{\mathrm{s} \text {, max }}$

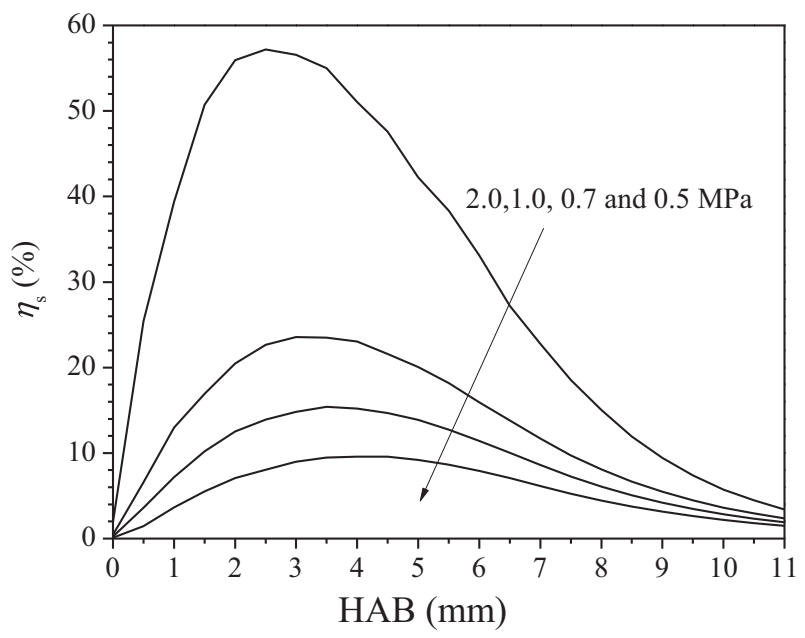

Fig. 5. Percentage of carbon in the fuel converted to soot as a function of axial location along the flame at 0.5 2.0 MPa.

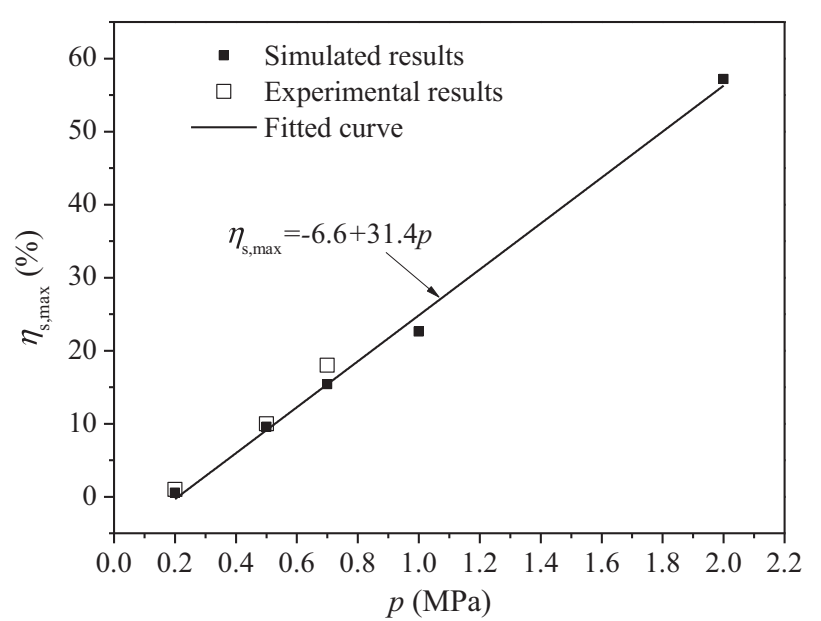

Fig. 6. Maximum percentage of carbon conversion from fuel to soot as a function of pressure.

as a function of pressure, and the simulated and experimental results well agree at 0.2 2.0 MPa [10]. The maximum percentage of carbon conversion is proportional to pressure $\left(\eta_{s, \max } \propto p\right)$, and soot formation is enhanced by increasing pressure.

Fig. 7 shows the distributions of soot, flame mixture fraction $(\zeta)$ and temperature. The results indicate that the maximum soot concentration occurs in the region where $\zeta$ and temperature are respectively $0.08 \sim 0.09$ and about $1200 \mathrm{~K}$. With the increase of pressure, soot volume fraction increases, and sooting region and flame surface (where $\zeta$ is equal to 0.055 ) become narrower. Great gradient of temperature near the burner exit enhances the thermal diffusion from the hot regions toward the center, which increases high fuel pyrolysis rate and accelerates soot nucleation and growth as the pressure increases.

Fig. 8 shows the maximum volume concentration of soot $\left(f_{v, \max }\right)$ and the axial location as a function of pressure. The results indicate that $f_{\mathrm{v}, \max }$ location decreases with the increase of pressure, and $f_{\mathrm{v}, \max }$ increases with pressure as $f_{\mathrm{v}, \max } \propto p^{2}$. With the increase of pressure, the great gradient of mixture fraction enhances molecular diffusion and accelerates soot oxidization, then $f_{\mathrm{v}, \max }$ location decreases. Compared to Fig. 5 and Fig. 8, the locations of $f_{\mathrm{v}, \max }$ and $\eta_{\mathrm{s} \text {,max }}$ are inconsistent, and $f_{\mathrm{v}, \max }$ and $\eta_{\mathrm{s}, \max }$ occur respectively at the middle and lower parts of flame height.

\subsection{Flame structure and reaction mechanism}

Although the flame shape varies with pressure, the flame structures are similar at different pressures, and the diffusion flame consists of three zones: fuel heating zone, fuel-rich reaction zone and oxidizer-rich reaction zone. Fig. 9 only shows the flame structure and the main species profiles in three flame zones at $0.5 \mathrm{MPa}$. In fuel heating zone, when fuel $n-\mathrm{C}_{7} \mathrm{H}_{16}$ comes out of nozzle exit, fuel temperature increases by thermal diffusion and convection, $n-\mathrm{C}_{7} \mathrm{H}_{16}$ is firstly decomposed into small molecule gases (e.g., $\mathrm{H}_{2}$, $\mathrm{CH}_{4}, \mathrm{C}_{2} \mathrm{H}_{2}, \mathrm{C}_{2} \mathrm{H}_{4}, \mathrm{C}_{2} \mathrm{H}_{6}, \mathrm{C}_{3} \mathrm{H}_{4}, \mathrm{C}_{3} \mathrm{H}_{6}$, etc.) in inner side of flame $(R<1.4 \mathrm{~mm}$ at $\mathrm{HAB}=1 \mathrm{~mm})$ shown in Fig. 9b. In fuel-rich reaction zone in inner side of flame $(R<0.7 \mathrm{~mm}$ at $\mathrm{HAB}=5 \mathrm{~mm})$ in Fig. 9c, PAHs and soot are formed. PAHs include $\mathrm{C}_{6} \mathrm{H}_{6}, \mathrm{C}_{8} \mathrm{H}_{8}$ and $\mathrm{C}_{10} \mathrm{H}_{8}$, and soot precursors include $\mathrm{C}_{2} \mathrm{H}_{2}, \mathrm{C}_{6} \mathrm{H}_{5}, \mathrm{C}_{6} \mathrm{H}_{6}$ and $\mathrm{C}_{2} \mathrm{H}_{4}$ in the study. In oxidizer-rich reaction zone (at $\mathrm{HAB}=5 \mathrm{~mm}$ ) in Fig. 9d, the reaction zone turns into a partially premixed flame where oxygen intensively penetrates into the flame zone, a large amount of $\mathrm{OH}$ radical is formed in high temperature condition, and PAHs and soot are oxidized. 


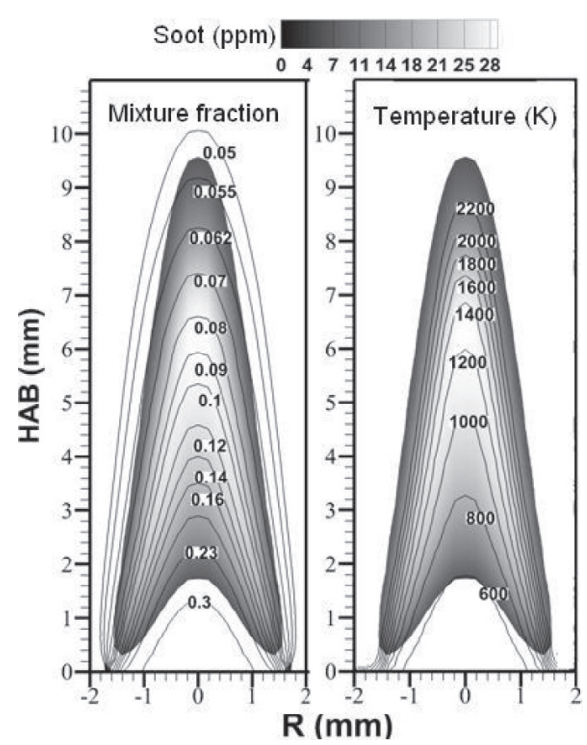

(a) $0.7 \mathrm{MPa}$

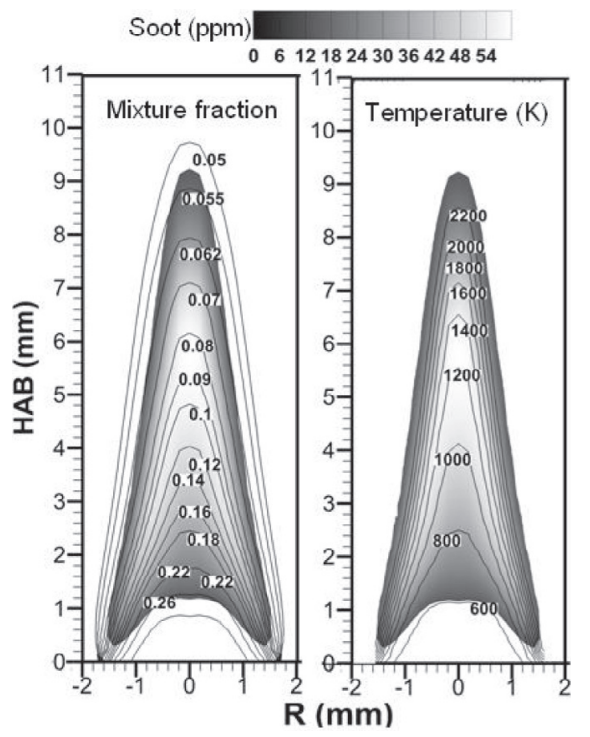

(b) $1.0 \mathrm{MPa}$

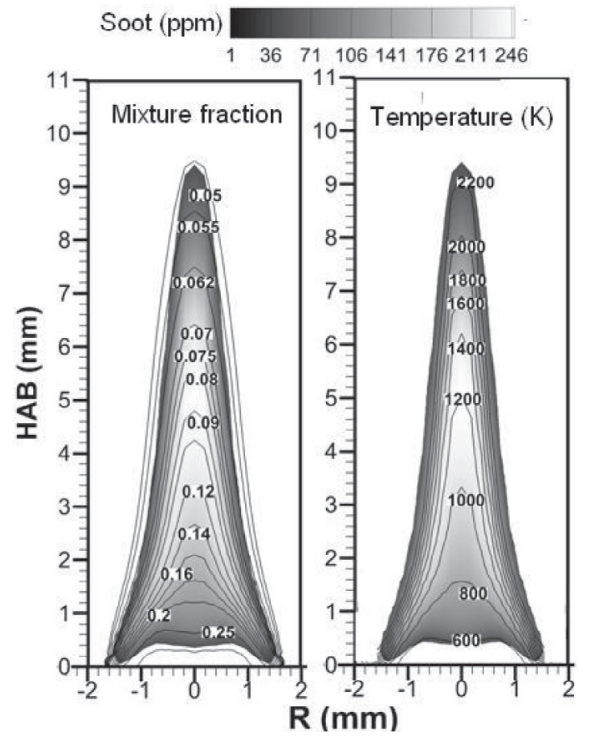

(c) $2.0 \mathrm{MPa}$

Fig. 7. Soot concentration distribution and the contours of mixture fraction and temperature in flame at different pressure.

To investigate reaction mechanism of above-mentioned three zones of flame, the reaction pathway flux analysis is performed using MixMaster (a Python program that is part of the Cantera suite), in which the integral path analysis is based on a conserved scalar approach to reaction fluxes. Fig. 10 illustrates the detailed reaction pathway diagrams for C-containing species of the three zones of flame shown in Fig. 9 at $0.5 \mathrm{MPa}$, where the relative width of the arrows indicates pathway importance.

Fig. 10a provides the reaction paths of main C-containing species in the fuel heating zone. First, hydrogen abstraction reactions are the dominant pathway with the increase of temperature, and $\mathrm{H}$ abstraction of $n$-heptane by $\mathrm{H}$ radical is

$$
\mathrm{C}_{7} \mathrm{H}_{16}+\mathrm{H}=\mathrm{C}_{7} \mathrm{H}_{15}+\mathrm{H}_{2}
$$

At the meantime, the thermal decomposition reaction of $\mathrm{C}_{7} \mathrm{H}_{15}$ becomes important:

$\mathrm{C}_{7} \mathrm{H}_{15}=\mathrm{C}_{2} \mathrm{H}_{4}+\mathrm{C}_{2} \mathrm{H}_{5}+\mathrm{C}_{3} \mathrm{H}_{6}$

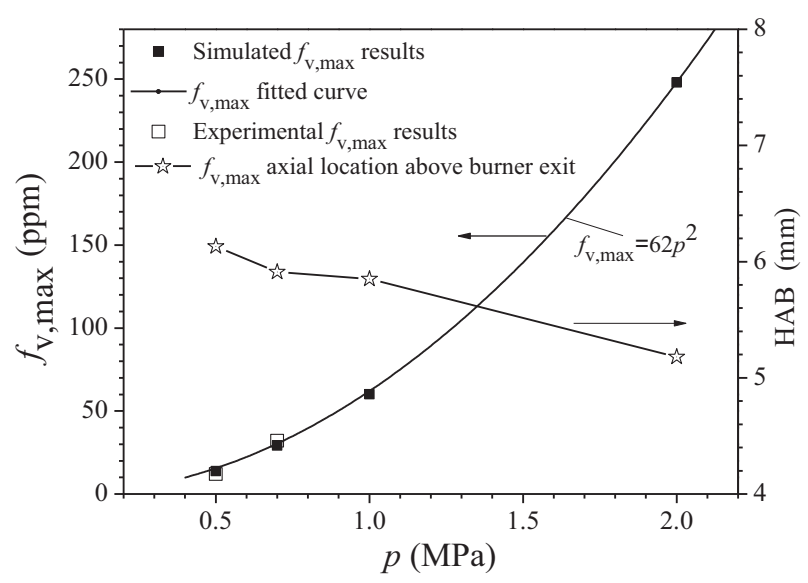

Fig. 8. Maximum soot volume concentration and the axial location as a function of pressure. 


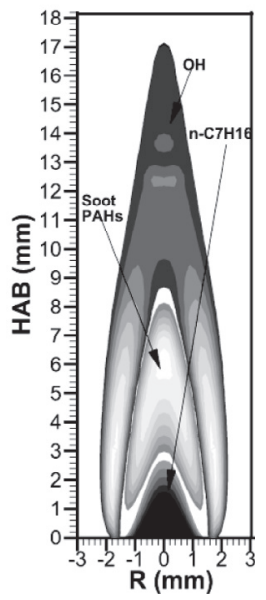

(a) flame structure

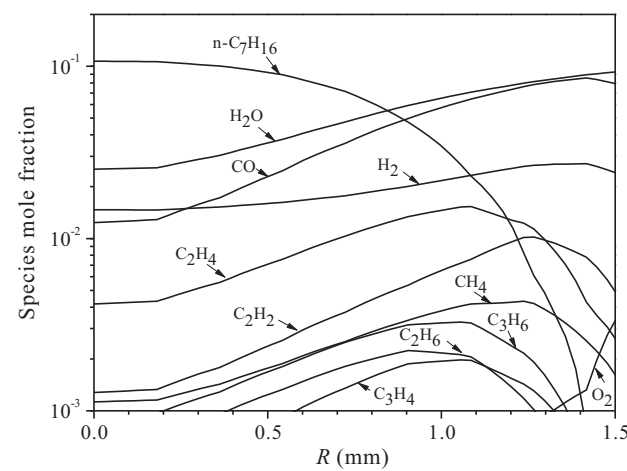

(b) at $\mathrm{HAB}=1 \mathrm{~mm}$ in fuel heating zone
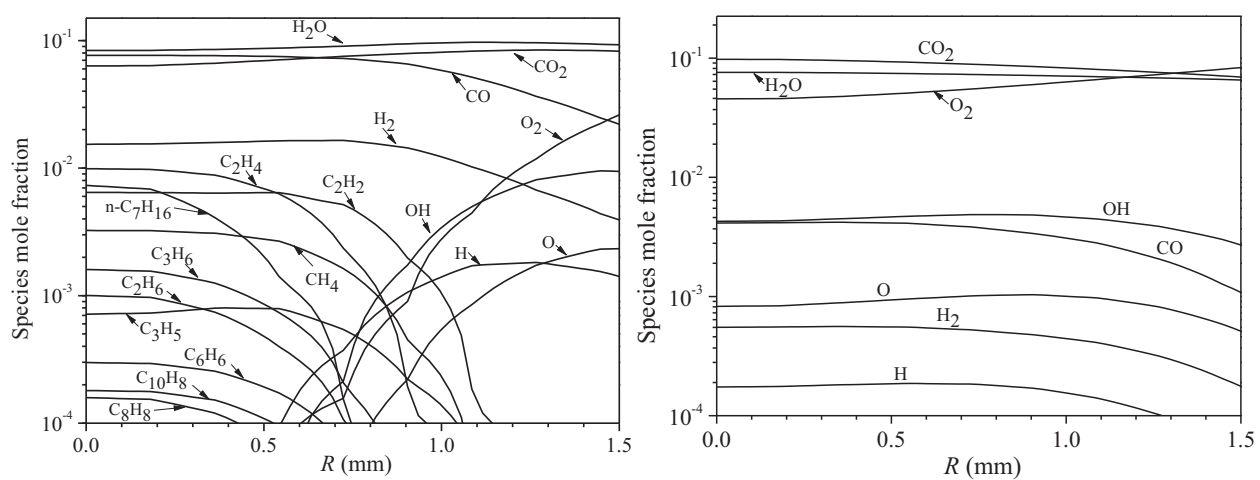

(c) at $\mathrm{HAB}=5 \mathrm{~mm}$ in fuel-rich reaction zone

(d) at $\mathrm{HAB}=10 \mathrm{~mm}$ in oxidizer-rich reaction zone

Fig. 9. The flame structure and the main species profiles on the flame cross section of the three zones at $0.5 \mathrm{MPa}$.

$\mathrm{C}_{2} \mathrm{H}_{2}, \mathrm{C}_{2} \mathrm{H}_{6}$ and $\mathrm{CH}_{4}$ are formed by $\mathrm{H}$ addition reactions:

$\mathrm{C}_{2} \mathrm{H}+\mathrm{H}+\mathrm{M}=\mathrm{C}_{2} \mathrm{H}_{2}+\mathrm{M}$

$\mathrm{CH}_{3}+\mathrm{H}(+\mathrm{M})=\mathrm{CH}_{4}(+\mathrm{M})$

$\mathrm{C}_{2} \mathrm{H}_{5}+\mathrm{H}=\mathrm{C}_{2} \mathrm{H}_{6}$

$\mathrm{C}_{3} \mathrm{H}_{4}$ is formed by following reaction:

$\mathrm{C}_{3} \mathrm{H}_{5}+\mathrm{C}_{2} \mathrm{H}_{5}=\mathrm{C}_{2} \mathrm{H}_{6}+\mathrm{C}_{3} \mathrm{H}_{4}$

As known from Fig. 10a, a large amount of CO is produced by the $\mathrm{H}$ addition reaction of $\mathrm{HCO}$ :

$\mathrm{HCO}+\mathrm{H}=\mathrm{H}_{2}+\mathrm{CO}$

Fig. 10b provides the reaction paths of main C-containing species in the fuel-rich reaction zone. Large amounts of PAHs $\left(\mathrm{C}_{6} \mathrm{H}_{6}, \mathrm{C}_{8} \mathrm{H}_{8}\right.$ and $\left.\mathrm{C}_{10} \mathrm{H}_{8}\right)$ and soot precursors $\left(\mathrm{C}_{2} \mathrm{H}_{2}, \mathrm{C}_{6} \mathrm{H}_{5}, \mathrm{C}_{6} \mathrm{H}_{6}\right.$ and $\left.\mathrm{C}_{2} \mathrm{H}_{4}\right)$ are formed. Benzene $\left(\mathrm{C}_{6} \mathrm{H}_{6}\right)$ is mainly produced by the reaction of $\mathrm{C}_{4} \mathrm{H}_{5}$ and $\mathrm{C}_{2} \mathrm{H}_{2}$ :

$$
\mathrm{C}_{4} \mathrm{H}_{5}+\mathrm{C}_{2} \mathrm{H}_{2}=\mathrm{C}_{6} \mathrm{H}_{6}+\mathrm{H}
$$

Main consumption of benzene produces phenyl radicals $\left(\mathrm{C}_{6} \mathrm{H}_{5}\right)$ through the following reaction:
$\mathrm{C}_{6} \mathrm{H}_{6}+\mathrm{OH}=\mathrm{C}_{6} \mathrm{H}_{5}+\mathrm{H}_{2} \mathrm{O}$

Styrene $\left(\mathrm{C}_{8} \mathrm{H}_{8}\right)$ is produced by the following reactions:

$\mathrm{C}_{4} \mathrm{H}_{5}+\mathrm{C}_{4} \mathrm{H}_{4}=\mathrm{C}_{8} \mathrm{H}_{8}+\mathrm{H}$

$2 \mathrm{C}_{4} \mathrm{H}_{4}=\mathrm{C}_{8} \mathrm{H}_{8}$

The naphthalene $\left(\mathrm{C}_{10} \mathrm{H}_{8}\right)$ formation is achieved through the following reaction:

$\mathrm{C}_{4} \mathrm{H}_{5}+\mathrm{C}_{6} \mathrm{H}_{6}=\mathrm{C}_{10} \mathrm{H}_{8}+\mathrm{H}_{2}+\mathrm{H}$

The formation of the first aromatic ring is a key-point in soot formation. In the skeletal mechanism, the formation of $\mathrm{C}_{6} \mathrm{H}_{6}$ and $\mathrm{C}_{6} \mathrm{H}_{5}$ is the start point for the growth of a soot particle.

Oxygen-rich zone exists with a large amount of oxidizing species $\left(\mathrm{O}_{2}, \mathrm{OH}\right.$ and $\mathrm{O}$ free radicals, see Fig. $\left.9 \mathrm{~d}\right)$, and Fig. 10c shows the dominant oxidization reaction paths:

$\mathrm{CO}+2 \mathrm{OH}=\mathrm{CO}_{2}+\mathrm{H}_{2} \mathrm{O}$

It is believed that these oxidizing species are the main culprits that are responsible for the destruction of the soot particle [10]; soot and PAHs entering from the fuel-rich zone are decomposed and oxidized, and the light gases are also oxidized in the zone. 


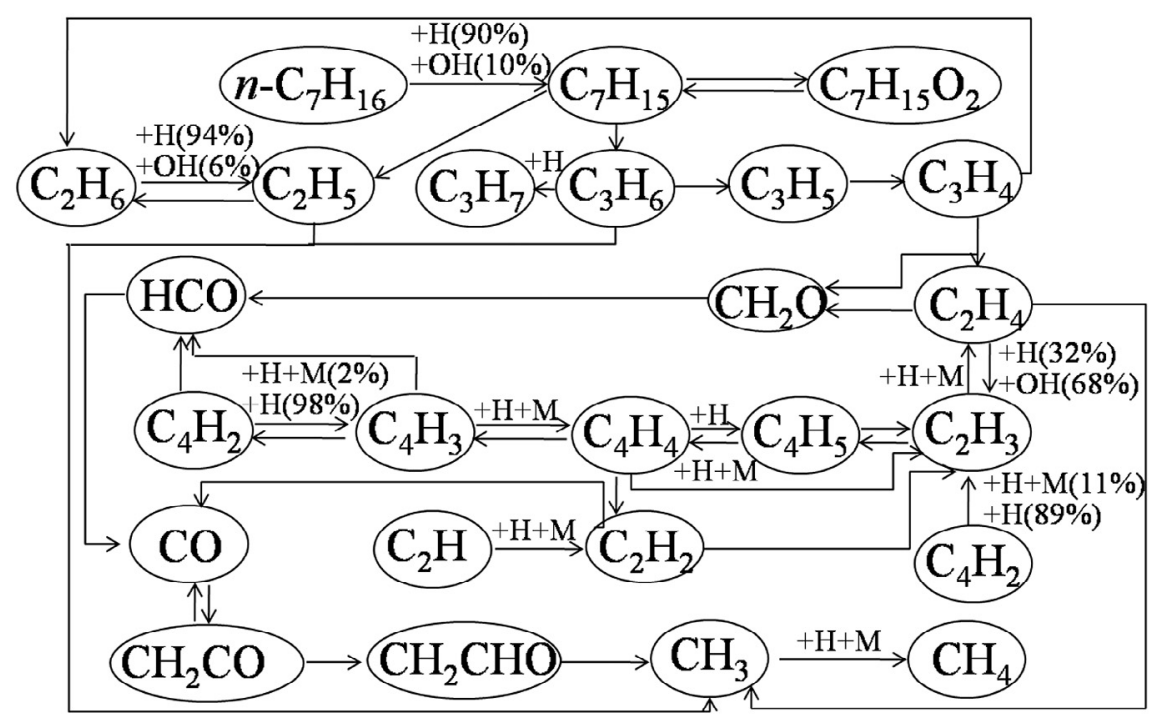

(a)

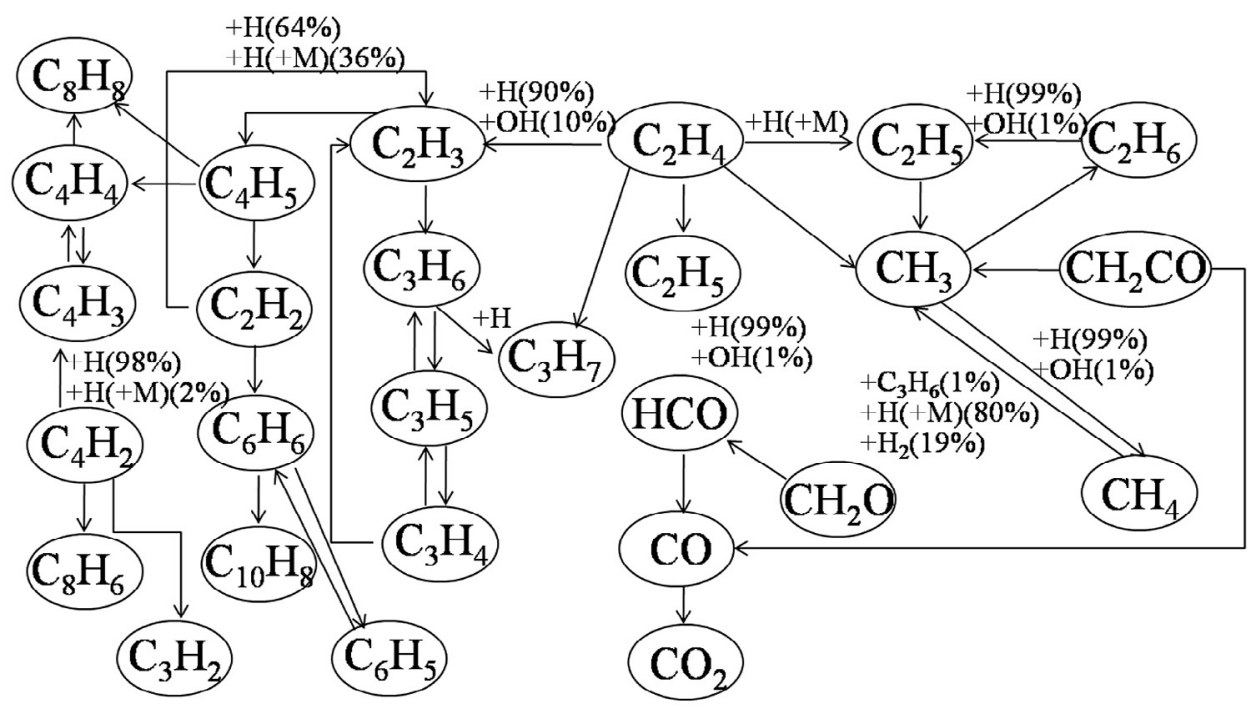

(b)

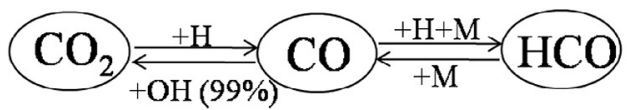

(c)

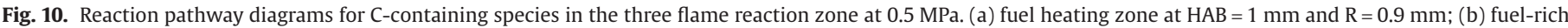
zone at $\mathrm{HAB}=5 \mathrm{~mm}$ and $\mathrm{R}=0.3 \mathrm{~mm}$; (c) oxygen-rich zone at $\mathrm{HAB}=10 \mathrm{~mm}$ and $\mathrm{R}=0 \mathrm{~mm}$.

\section{Conclusions}

Pressure effects on flame structure and soot formation of $n$-heptane/air co-flow laminar are investigated using the developed skeletal reaction mechanism, and the reaction paths in the three zones of flame were presented. The following conclusions can be drawn:

(1) With the increase of pressure, flame height keeps constant (about $9 \mathrm{~mm}$ ) at 0.7 3.0 MPa, and the flame radius decreases as $r_{\mathrm{f}} \propto p^{-1 / 2}$.
(2) The relationship between the maximum volume concentration of soot and pressure is in the form of $f_{\mathrm{v}, \max } \propto p^{2}$; the maximum percentage of carbon in the fuel converted to soot is proportional to pressure $\left(\eta_{s, \max } \propto p\right)$ at $0.1 \sim 2.0 \mathrm{MPa}$; the locations of $f_{\mathrm{v}, \max }$ and $\eta_{\mathrm{s}, \max }$ are inconsistent, and $f_{\mathrm{v}, \max }$ and $\eta_{\mathrm{s}, \max }$ occur respectively at the middle and lower parts of flame height; $f_{\mathrm{v}, \max }$ occurs in the region where $\zeta$ and temperature are respectively 0.08 0.09 and about $1200 \mathrm{~K}$.

(3) The diffusion flame consists of three zones: fuel heating zone, fuel-rich reaction zone and oxidizer-rich reaction zone. In fuel heating zone, $n-\mathrm{C}_{7} \mathrm{H}_{16}$ is firstly decomposed into small 
molecule gas (e.g., $\mathrm{H}_{2}, \mathrm{CH}_{4}, \mathrm{C}_{2} \mathrm{H}_{2}, \mathrm{C}_{2} \mathrm{H}_{4}, \mathrm{C}_{2} \mathrm{H}_{6}, \mathrm{C}_{3} \mathrm{H}_{4}, \mathrm{C}_{3} \mathrm{H}_{6}$, etc.); in fuel-rich reaction zone, PAHs $\left(\mathrm{C}_{6} \mathrm{H}_{6}, \mathrm{C}_{8} \mathrm{H}_{8}\right.$ and $\left.\mathrm{C}_{10} \mathrm{H}_{8}\right)$ and soot precursors $\left(\mathrm{C}_{2} \mathrm{H}_{2}, \mathrm{C}_{6} \mathrm{H}_{5}, \mathrm{C}_{6} \mathrm{H}_{6}\right.$ and $\left.\mathrm{C}_{2} \mathrm{H}_{4}\right)$ are formed, and soot begins to grow through coagulation and agglomeration; in oxidizer-rich reaction zone, a large amount of $\mathrm{OH}$ radical is formed, and PAHs and soot are oxidized.

\section{Acknowledgement}

Financial support by National Natural Science Foundation of China (No. 51376189) is acknowledged.

\section{Appendix: Supplementary material}

Supplementary data to this article can be found online at doi:10.1016/j.applthermaleng.2016.03.006.

\section{Nomenclature}

$A_{\mathrm{f}} \quad$ Cross-sectional area $\left[\mathrm{mm}^{2}\right]$

$f_{\mathrm{v}, \max } \quad$ The maximum volume concentration of soot [ppm]

$\mathrm{HAB}$ The flame height above the burner lip [mm]

$p \quad$ Pressure [MPa]

PAHs Polycyclic aromatic hydrocarbons

PCA Principal component analysis

$r_{\mathrm{f}} \quad$ Flame radius [mm]

SR Stoichiometric ratio

$\zeta \quad$ The mixture fraction of fuel and oxidizer

$\eta_{\mathrm{s}} \quad$ The percentage conversion of soot [\%]

$\eta_{\mathrm{s}, \max } \quad$ The maximum percentage conversion of soot [\%]

$\tau_{\text {ign }} \quad$ Ignition delay time $[\mu s]$

\section{References}

[1] K.B. Showry, Soot processes in diesel engines - Review, IPASJ IJME 3 (4) (2015) $1-9$.

[2] X. Li, Z. Xu, C. Guan, Z. Huang, Impact of exhaust gas recirculation (EGR) on soot reactivity from a diesel engine operating at high load, Appl. Therm. Eng. $68(1-2)$ (2014) 100-106.

[3] L. Carver, Black Carbon and Climate Change: Exploring the Policy Options for Reducing Emissions from Diesel Fuel Consumption in the United States, Tufts University, Medford, MA, 2011.

[4] D. Kim, B.M. Kumfer, C. Anastasio, I.M. Kennedy, T.M. Young, Environmental aging of polycyclic aromatic hydrocarbons on soot and its effect on source identification, Chemosphere 76 (8) (2009) 1075-1081.
[5] A.E. Bakali, J.L. Delfau, C. Vovelle, Measurement of soot volume fraction and gaseous species concentrations in premixed n-heptane and iso-octane flames, J Chim Phys Physicochim Biol. 94 (9) (1997) 1659-1673.

[6] R. Seiser, H. Pitsch, K. Seshadri, W.J. Pitz, H.J. Gurran, Extinction and autoignition of $n$-heptane in counterflow configuration, Proc. Combust. Inst. 28 (2) (2000) 2029-2037.

[7] B. Rohani, S.S. Park, C. Bae, Effect of injection strategy on smoothness, emissions and soot characteristics of PCCI-conventional diesel mode transition, Appl. Therm. Eng. 93 (25) (2016) 1033-1042.

[8] L. Zhou, N.J. Dam, M.D. Boot, L.P.H. Goey, Measurements of sooting tendency in laminar diffusion flames of $n$-heptane at elevated pressure, Combust. Flame 160 (11) (2013) 2507-2516

[9] A. Khosousi, F. Liu, S.B. Dworkin, N.A. Eaves, M.J. Thomson, X. He, et al., Experimental and numerical study of soot formation in laminar coflow diffusion flames of gasoline/ethanol blends, Combust. Flame 162 (10) (2015) 39253933.

[10] A.K. Karatas, G. Intasopa, O.L. Gülder, Sooting behaviour of $n$-heptane laminar diffusion flames at high pressures, Combust. Flame 160 (9) (2013) 1650-1656.

[11] F. Inal, S.M. Senkan, Effects of equivalence ratio on species and soot concentrations in premixed $n$-heptane flames, Combust. Flame 131 (1-2) (2002) 16-28.

[12] G.L. Agafonov, I. Naydenova, P. Vlasov, J. Warnatz, Detailed kinetic modeling of soot formation in shock tube pyrolysis and oxidation of toluene and n-heptane, Proc. Combust. Inst. 31 (1) (2007) 75-83.

[13] A. D. Anna, M. Alfe, B. Apicella, A. Tregrossi, A. Ciajolo, Effect of fuel/air ratio and aromaticity on sooting behavior of premixed heptane flames, Energy Fuels 21 (5) (2007) 2655-2662.

[14] H.I. Joo, O.L. Gülder, Soot formation and temperature field structure in coflow laminar methane-air diffusion flames at pressures from 10 to $60 \mathrm{~atm}$, Proc. Combust. Inst. 32 (1) (2009) 769-775.

[15] J. Consalvi, F. Liu, Numerical study of the effects of pressure on soot formation in laminar coflow n-heptane/air diffusion flames between 1 and $10 \mathrm{~atm}$, Proc. Combust. Inst. 35 (2) (2015) 1727-1734.

[16] H. Wang, R.D. Reitz, M. Yao, B. Yang, Q. Jiao, L. Qiu, Development of an n-heptane-n-butanol-PAH mechanism and its application for combustion and soot prediction, Combust. Flame 160 (3) (2013) 504-519.

[17] V. Sandor, P. Valko, T. Turányi, Principal component analysis of kinetic models, Int. J. Chem. Kinet. 17 (1) (1985) 55-81.

[18] M. Hartmann, I. Gushterova, M. Fikri, C. Schulz, Auto-ignition of toluene-doped n-heptane and iso-octane/air mixtures: high-pressure shock-tube experiments and kinetics modeling, Combust. Flame 158 (1) (2011) 172-178.

[19] F. Liu, K.A. Thomson, H. Guo, G.J. Smallwood, Numerical and experimental study of an axisymmetric coflow laminar methane-air diffusion flame at pressures, Combust. Flame 146 (3) (2006) 456-471.

[20] Z. Wen, S. Yun, M.J. Thomson, M.F. Lightstone, Modeling soot formation in turbulent kerosene/air jet diffusion flames, Combust. Flame 135 (3) (2003) 323-340.

[21] F. Xu, Z. Dai, G.M. Faeth, Flame and soot boundaries of laminar jet diffusion flames, AIAA J. 40 (12) (2002) 2441-2446.

[22] D.S. Bento, K.A. Thomson, O.L. Gülder, Soot formation and temperature field structure in laminar propane-air diffusion flames at elevated pressures, Combust. Flame 14 (4) (2006) 5765-5778.

[23] K.A. Thomson, O.L. Gülder, E.J. Weckman, R.A. Fraser, G.J. Smallwood, D.R. Snelling, Soot concentration and temperature measurements in co-annular, nonpremixed $\mathrm{CH}_{4} /$ air laminar flames at pressures up to $4 \mathrm{MPa}$, Combust. Flame 140 (3) (2005) 222-232.

[24] L.L. McCrain, W.L. Roberts, Measurements of the soot volume field in laminar diffusion flames at elevated pressures, Combust. Flame 140 (1-2) (2005) 6069. 